\title{
Stimulation of Sugar Transport in Rat Soleus Muscle by Prolonged Cooling at $0^{\circ} \mathrm{C}$
}

\author{
K. T. Yu and M. K. Gould \\ Department of Biochemistry, Monash University, Clayton, Victoria, Australia
}

Summary. The uptake of D-xylose by isolated rat soleus muscle (measured at $37^{\circ} \mathrm{C}$ ) was stimulated by prolonged cooling at $0{ }^{\circ} \mathrm{C}$. The effect of cooling reached a maximum value after $3 \mathrm{~h}$ and was reversed on rewarming; reversal was temperature-dependent. Cooling stimulated xylose uptake sub-maximally compared with the effect of insulin (100 U/1). Xylose uptake in cooled muscle was further stimulated by insulin, but not by anoxia. The effect of cooling and its reversal were still demonstrable in the presence of ouabain $(1 \mathrm{mmol} / \mathrm{l})$, or when unidirectional efflux of calcium and magnesium from the muscle was induced by EDTA ( $5 \mathrm{mmol} / \mathrm{l})$. The ionophore, A23187 $(2.5 \mathrm{mg} / 1)$, depressed the effect of cooling in the presence of EDTA but not in the presence of EGTA. It is concluded that cooling disrupts an intracellular magnesium-pump and that muscle sugar transport is consequentially stimulated through an increase in cytoplasmic magnesium.

Key words: Sugar transport, cooling, insulin, anoxia, ouabain, calcium-efflux, magnesium-efflux, EDTA, EGTA, ionophore A23187, magnesium-pump, rat soleus muscle.

The process of sugar transport in muscle is subject to regulation both externally by circulating hormones, notably insulin [1], and internally by the metabolic state of the cell itself [2]. Considerable attention has been directed towards the regulation of sugar transport in an attempt to explain the mechanism of insulin action. It has been shown that there are many factors that are not part of the normal regulatory system in vivo which, nevertheless, can be used as experimental probes to examine the mechanisms involved in the regulation of sugar transport (for reviews see $[1-4]$ ).
Three major mechanisms have been proposed which explain in part the action of some of these effectors. First, that anoxia and uncouplers of oxidative phosphorylation activate sugar transport by lowering muscle ATP [5, 6]. Second, that the action of insulin and certain oxidising agents appears to be concerned with the oxidation of some essential sulphydryl group(s) [7]. This in turn has led to the suggestion that hydrogen peroxide may mediate the action of certain effectors [8], including insulin itself [9]. Third, that the activation of the sugar transport system is achieved through an increase in the concentration of cytoplasmic free calcium $[3,10]$. What is lacking is some systematic study of these various factors so that their effects can be integrated into a single overall model. Furthermore, most of this information has been derived from studies using the adipocyte, heart and diaphragm; how relevant this may be to the sugar transport system in skeletal muscle remains to be seen.

We have initiated a project which seeks, by studying in depth the effects of a broad range of effectors, to define the various mechanisms involved in the regulation of sugar transport in rat soleus muscle. Previous reports from this laboratory have described the effects of anoxia and uncouplers of oxidative-phosphorylation [6,11, 12] and EDTA [13]; this paper is concerned with the stimulatory effect of prolonged cooling at $0{ }^{\circ} \mathrm{C}$ on muscle sugar transport. This was first reported by Clausen et al. [10] and confirmed in this laboratory [14]. These experiments examined the possibility that the stimulatory effect of cooling may be due to shifts in cations between the intracellular and extracellular compartments, when energy metabolism was depressed by extended incubation at $0{ }^{\circ} \mathrm{C}$. The results presented below suggest that the effect of cooling on sugar transport is more likely due to the disruption of an intracellular cation gradient involved in the regulation of cytoplasmic magnesium concentrations. 


\section{Methods}

Soleus muscles weighing approximately $30 \mathrm{mg}$ were obtained from Sprague Dawley rats $(70-90 \mathrm{~g})$ fed ad libitum. Muscles were incubated under an atmosphere of $\mathrm{O}_{2}-\mathrm{CO}_{2}(95: 5, \mathrm{v} / \mathrm{v})$; anacrobic incubations were under $\mathrm{N}_{2}-\mathrm{CO}_{2}(95: 5, \mathrm{v} / \mathrm{v})$. The basic medium ("bicarbonate medium") contained $\mathrm{NaCl}(118 \mathrm{mmol} / \mathrm{l}), \mathrm{KCl}$ (4.8 mmol/l), $\mathrm{CaCl}_{2}(2.6 \mathrm{mmol} / \mathrm{l}), \mathrm{MgSO}_{4}(1.2 \mathrm{mmol} / 1), \mathrm{KH}_{2} \mathrm{PO}_{4}$ $(1.2 \mathrm{mmol} / \mathrm{l})$ and $\mathrm{NaHCO}_{3}(25 \mathrm{mmol} / \mathrm{l})$; before use, the medium was gassed with the appropriate gas mixture. Additions to, or variations from, this basic medium are detailed in the text.

Xylose uptake was determined using the method of Korbl et al. [6]. In this procedure the muscles are first preincubated under the test conditions; the uptake of $\mathrm{D}-\left[\mathrm{U}^{-14} \mathrm{C}\right] \mathrm{xylose}$ (final conc. $10 \mathrm{mmol} / \mathrm{l}$, sp. act. $0.03 \mu \mathrm{Ci} / \mu \mathrm{mol})$ is then measured over a $5 \mathrm{~min}$ period at $37^{\circ} \mathrm{C}$, using D-[1- $\left.{ }^{3} \mathrm{H}\right] \operatorname{sorbitol}(10 \mathrm{mmol} / 1$, sp. act. $0.1 \mu \mathrm{Ci} /$ $\mu \mathrm{mol})$ as an extracellular marker. Irrespective of the preincubation temperature, xylose uptake was always determined at $37^{\circ} \mathrm{C}$. ATP was determined spectrophotometrically as described previously [6].

For the measurement of $\mathrm{K}^{+}$-efflux the muscles were pre-incubated in $0.5 \mathrm{ml}$ of bicarbonate medium in sealed glass vials $(15 \mathrm{~mm}$ diam.). At the end of the incubation the muscle was removed, the incubation medium was diluted 50 -fold with water, and $\mathrm{K}^{+}$determined using a Varian Techtron Model 1000 Atomic Absorption Spectrophotometer (Varian, Melbourne). For the measurement of $\mathrm{Ca}^{2+}$ - and $\mathrm{Mg}^{2+}$-efflux the medium was modified by the omission of $\mathrm{Ca}^{2+}$ and $\mathrm{Mg}^{2+}$; this will be referred to as " $\mathrm{Ca}^{2+} / \mathrm{Mg}^{2+}$-free" medium. Prior to assay the medium was diluted with an equal volume of $\mathrm{KCl}$ solution $(134 \mathrm{mmol} / \mathrm{l}) ; \mathrm{Ca}^{2+}$ and $\mathrm{Mg}^{2+}$ were determined by atomic absorption spectrophotometry.

\section{Statistics}

To minimise the effect of biological variation between individual animals, wherever possible the experiments were designed using paired controls. One muscle from each pair was incubated under test conditions, while the second served as the control. The results of these experiments were analysed for statistical significance using Student's t-test as applied to paired samples. Where it was not possible to use paired controls, muscles taken from litter mates were distributed randomly among the experimental groups and the results subjected to statistical analysis using the standard Student's t-test.

\section{Materials}

D- $\left[\mathrm{U}-{ }^{14} \mathrm{C}\right] \mathrm{xylose}$ was obtained from The Radiochemical Centre, Amersham. D- $\left[1{ }^{3} \mathrm{H}\right]$ sorbitol was obtained from New England Nuclear, Boston. Beef insulin, twice recrystallised, was from the Commonwealth Serum Laboratories, Melbourne. A23187, ethylene-glycol-bis-( $\beta$-aminoethyl ether)- $\mathrm{N}, \mathrm{N}, \mathrm{N}^{\prime}, \mathrm{N}^{\prime}$-tetraacetic acid ("EGTA") and ouabain were from Calbiochem-Behring (Australia); EDTA was from British Drug Houses. EDTA and EGTA solutions were neutralised with $\mathrm{NaOH}$.

\section{Results}

\section{Stimulatory Effect of Cooling on Sugar Transport}

Preincubation at $0{ }^{\circ} \mathrm{C}$ stimulated the uptake of xylose by rat soleus muscle by up to $125 \%$ (Fig. 1). This effect was maximal after $3 \mathrm{~h}$ at $0{ }^{\circ} \mathrm{C}$ and was promptly re- versed when cooled muscles were returned to $37^{\circ} \mathrm{C}$ (Fig. 2); reversal occurred more slowly at $20^{\circ} \mathrm{C}$ than at $37^{\circ} \mathrm{C}$. The experiments presented in Figure 3 examined the relationship between the stimulatory effects of cooling and insulin on sugar transport. In order to allow the hormone time to interact with the tissue [6], the muscles were preincubated with insulin for $15 \mathrm{~min}$ at $37^{\circ} \mathrm{C}$ before the $3 \mathrm{~h}$ cooling period. In the presence of a sub-maximal concentration of insulin $(100 \mathrm{mU} / \mathrm{l})$, xylose uptake was further stimulated by cooling; however, there was no effect of cooling when xylose uptake was stimulated maximally by insulin $(100 \mathrm{U} / 1)$. Xylose uptake in cooled muscles was further stimulated by pre-exposure to both sub-maximal and supra-maximal concentrations of insulin.

The relationship between the effects of cooling and anoxia on muscle sugar transport was also studied. For these experiments the muscles were preincubated for $30 \mathrm{~min}$ at $37^{\circ} \mathrm{C}$ to achieve maximal stimulation of sugar transport by anoxia [6]. Cooling the muscle after anaerobic preincubation did not further stimulate xylose uptake (anaerobic muscle, $6.5 \pm 0.7 \mu \mathrm{mol} \mathrm{g}^{-1} \mathrm{~h}^{-1}$ versus anaerobic-cooled, $6.5 \pm 0.6 \mu \mathrm{mol} \mathrm{g}^{-1} \mathrm{~h}^{-1}, n=5$ ). Similarly, anoxia did not stimulate sugar transport beyond the effect of cooling (cooled muscle, $7.3 \pm 0.7 \mu \mathrm{mol} \mathrm{g}^{-1} \mathrm{~h}^{-1}$ versus anaerobic-cooled, $7.3 \pm 0.5 \mu \mathrm{mol} \mathrm{g}^{-1} \mathrm{~h}^{-1}, n=5$ ).

\section{Effect of Cooling on $\mathrm{K}^{+}$- Efflux}

The observation that the stimulatory effect of cooling was reversed more slowly at $20^{\circ} \mathrm{C}$ than at $37^{\circ} \mathrm{C}$, and the inability of cooling to stimulate sugar transport in anaerobic muscle, suggested that the stimulatory effect of cooling on sugar transport was somehow due to the suspension of metabolic activity when the muscles were held at $0{ }^{\circ} \mathrm{C}$. The experiments which follow examined the possibility that the effect of cooling and its reversal on rewarming may be due to the disruption and subsequent re-establishment of some energydependent ionic gradient(s).

The first system so examined was the $\mathrm{Na}^{+} /$ $\mathrm{K}^{+}$pump. According to Bihler, sugar transport in rat diaphragm [15] and smooth muscle [16] is stimulated by the inhibition of the $\mathrm{Na}^{+}$-pump. When soleus muscles were incubated for $3 \mathrm{~h}$ at $0^{\circ} \mathrm{C}, \mathrm{K}^{+}$was released into the incubation medium to the extent of $22 \mu \mathrm{mol} \mathrm{K}^{+} / \mathrm{g}$ muscle (Fig. 4). When these muscles were now incubated for a further $15 \mathrm{~min}$ at $37^{\circ} \mathrm{C}$, more than half of the $\mathrm{K}^{+}$which had appeared in the medium was taken up by the muscle. These changes in $\mathrm{K}^{+}$flux during the cooling period and on rewarming are consistent with the operation of the $\mathrm{Na}^{+} /$ $\mathrm{K}^{+}$pump at $37^{\circ} \mathrm{C}$ but not at $0{ }^{\circ} \mathrm{C}$. This also suggests prima facie that the effects of cooling and rewarming 


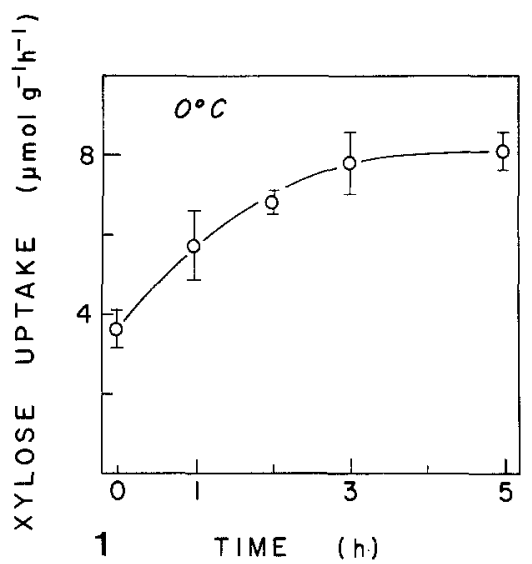

Fig. 1. Effect of cooling on xylose uptake by soleus muscle. Soleus muscles were incubated for up to $5 \mathrm{~h}$ at $0^{\circ} \mathrm{C}$ in $0.95 \mathrm{ml}$ of bicarbon ate medium. At the times shown, $\left[\mathrm{U}-{ }^{14} \mathrm{C}\right] x y l o s e$ and $\left[1-{ }^{3} \mathrm{H}\right]$ sorbitol were added in a volume of $50 \mu \mathrm{l}$; the incubation was then continued for $5 \mathrm{~min}$ at $37^{\circ} \mathrm{C}$ for the determination of xylose uptake. Each point represents the mean \pm SEM of five to six determinations

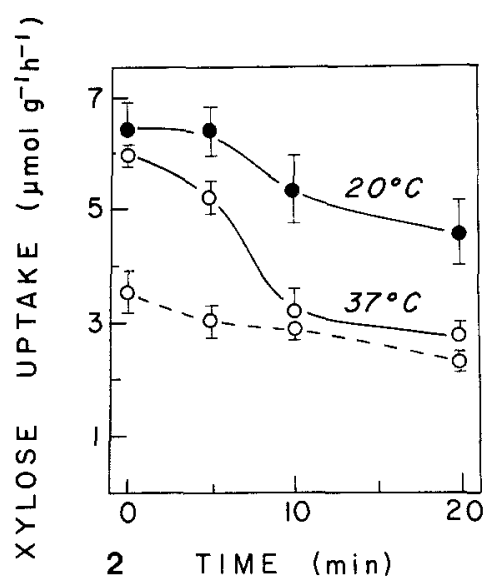

Fig. 2. Reversal of the stimulatory effect of cooling on xylose uptake. Soleus muscles were first preincubated for $3 \mathrm{~h}$ at $0^{\circ} \mathrm{C}$ in $0.95 \mathrm{ml}$ of bicarbonate medium. The muscles were then incubated for up to $20 \mathrm{~min}$ at either $37^{\circ} \mathrm{C}(\mathrm{O}-\mathrm{O})$ or $20^{\circ} \mathrm{C}(\longrightarrow)$. At the times shown $\left[\mathrm{U}-{ }^{14} \mathrm{C}\right] x y l o s e$ and $\left[1-{ }^{3} \mathrm{H}\right]$ sorbitol were added in a volume of $50 \mu \mathrm{l}$ and the muscles incubated a further $5 \mathrm{~min}$ at $37^{\circ} \mathrm{C}$ for the determination of xylose uptake. Xylose uptake was also determined in control muscles incubated, without prior cooling, for up to $20 \mathrm{~min}$ at $37^{\circ} \mathrm{C}(\mathrm{O}-\mathrm{O})$. Each point represents the mean $\pm \mathrm{SEM}$ of five determinations

on sugar transport could be related to effects on the $\mathrm{Na}^{+} / \mathrm{K}^{+}$pump.

It was argued that if this were so, then ouabain should inhibit the reversal of the cooling effect when cooled muscles are rewarmed. Soleus muscles were cooled for $3 \mathrm{~h}$ in the presence of ouabain $(1 \mathrm{mmol} / \mathrm{l})$ and then rewarmed for $15 \mathrm{~min}$ at $37^{\circ} \mathrm{C}$. As expected, ouabain eliminated the uptake of $\mathrm{K}^{+}$otherwise observed when cooled muscles were rewarmed. Instead, there was a further release of $\mathrm{K}^{+}$from these muscles

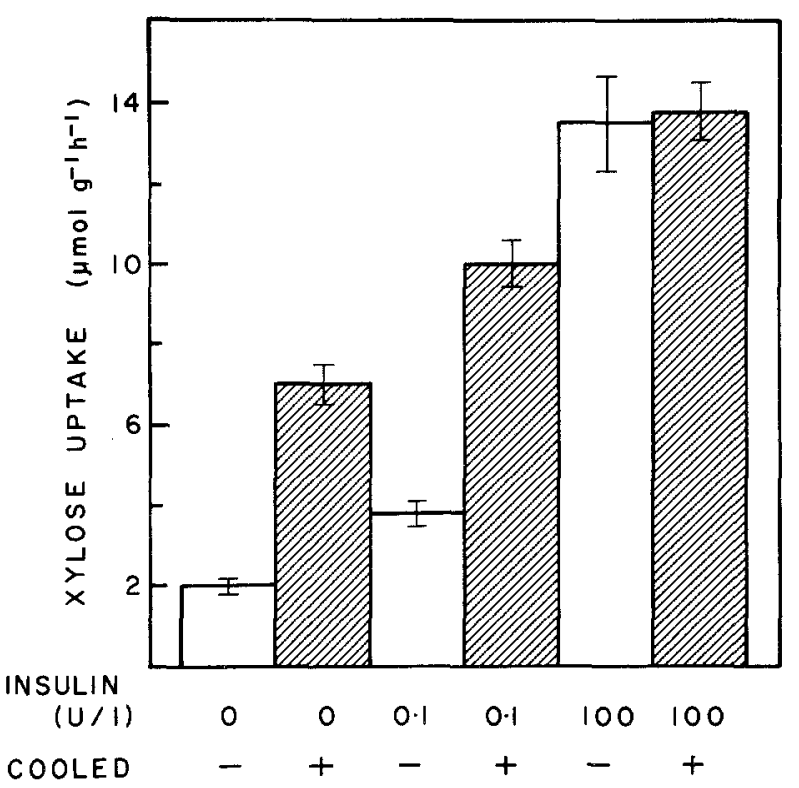

Fig. 3. Effects of cooling and insulin on sugar transport. Soleus muscles were first incubated for $15 \mathrm{~min}$ at $37^{\circ} \mathrm{C}$ in bicarbonate medium in the presence or absence of insulin as shown. Where indicated the incubation was continued for a further $3 \mathrm{~h}$ at $0^{\circ} \mathrm{C}$ in the same medium. Values are expressed as mean \pm SEM of five determinations

(Fig. 4). However, the stimulatory effect of cooling on xylose uptake was still reversed when muscles were cooled and then rewarmed in the presence of ouabain. Control experiments (not shown) confirmed that there was no effect on xylose uptake when muscles were exposed to ouabain for $15 \mathrm{~min}$ at $37^{\circ} \mathrm{C}$, or for $3 \mathrm{~h}$ at $0^{\circ} \mathrm{C}$. The complete absence of any effect of ouabain on basal xylose uptake by soleus muscle is in accord with the observations of Bihler [15] and Kohn and Clausen [17]; according to Bihler [15], ouabain does not stimulate basal sugar transport in rat hemidiaphragm unless the tissue is first preincubated with glucose. From the experiments presented in Figure 4, we may conclude that the effects of cooling and rewarming on the uptake of xylose by soleus muscle are not concerned with the sarcolemmal $\mathrm{Na}^{+}+\mathrm{K}^{+}$ATPase.

\section{Effect of Cooling $-\mathrm{Ca}^{2+}$ and $\mathrm{Mg}^{2+}$}

The experiments described in this section examined the possibility that the effect of cooling and its reversal may be concerned with the transport of $\mathrm{Ca}^{2+}$ or $\mathrm{Mg}^{2+}$ across the sarcolemma. Net efflux of $\mathrm{Ca}^{2+}$ and $\mathrm{Mg}^{2+}$ from soleus muscle was monitored using atomic absorption spectrophotometry. Using the standard bicarbonate buffer, which contains $2.6 \mathrm{mmol} \mathrm{CaCl}_{2} / 1$ and $1.2 \mathrm{mmol} \mathrm{MgSO}_{4} / \mathrm{l}$, it was not possible to detect changes in $\mathrm{Ca}^{2+}$ or $\mathrm{Mg}^{2+}$ when muscles were cooled 


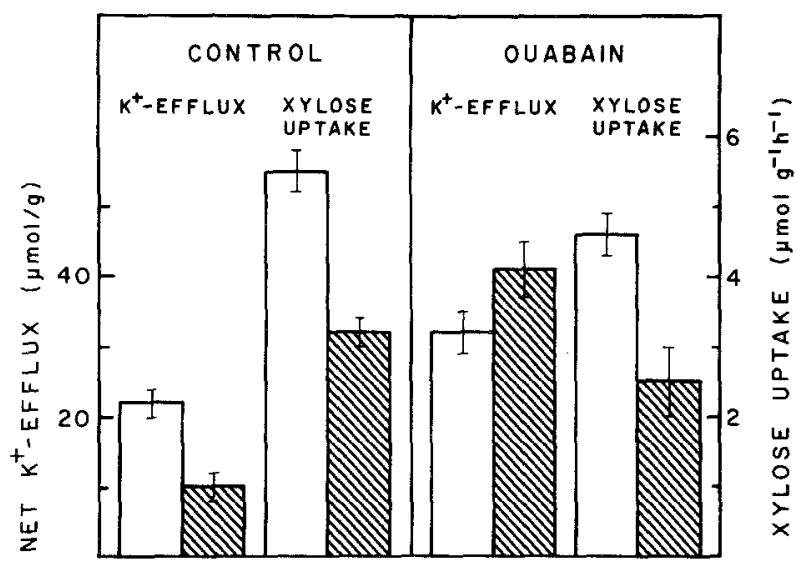

Fig. 4. Effect of cooling and rewarming on net $\mathrm{K}^{+}$-efflux and xylose uptake. Soleus muscles were incubated for $3 \mathrm{~h}$ at $0{ }^{\circ} \mathrm{C}$; one muscle from each pair was then incubated for a further $15 \mathrm{~min}$ at $37^{\circ} \mathrm{C}$ ("rewarmed"). Where indicated ouabain (1 mmol/l) was present in the incubation medium throughout the experiment. Net $\mathrm{K}^{+}$efflux indicates the extent to which $\mathrm{K}^{+}$was released into the medium at the end of the overall incubation period. $\square=$ cooled muscles, $=$ rewarmed muscles. Values are expressed as mean \pm SEM of five determinations

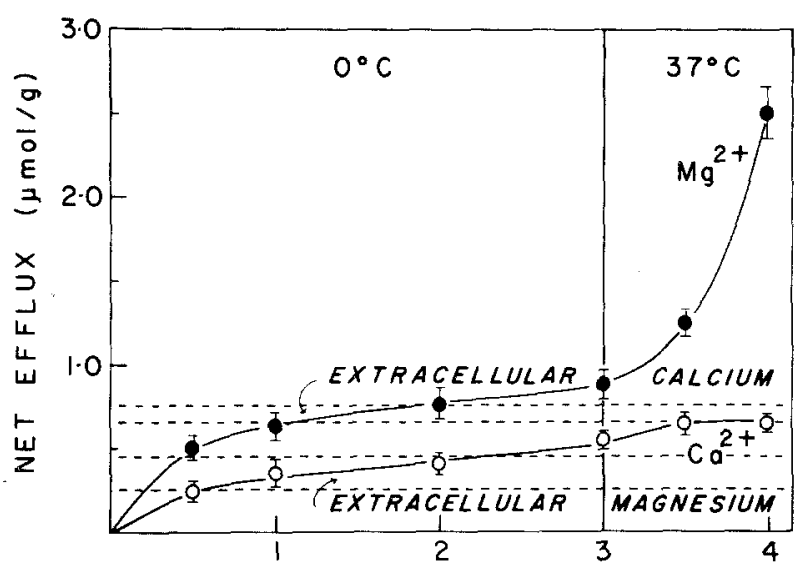

T I ME

(h)

Fig. 5. Net efflux of $\mathrm{Ca}^{2+}$ and $\mathrm{Mg}^{2+}$ from soleus muscle. Soleus muscles were incubated for up to $3 \mathrm{~h}$ at $0^{\circ} \mathrm{C}$ and then for up to $1 \mathrm{~h}$ at $37^{\circ} \mathrm{C}$ in $0.5 \mathrm{ml}$ of $\mathrm{Ca}^{2+} / \mathrm{Mg}^{2+}$-free medium containing EDTA $(5 \mathrm{mmol} / \mathrm{l}) . \ldots-$ indicate the upper and lower limits of the contribution of extracellular $\mathrm{Ca}^{2+}$ and $\mathrm{Mg}^{2+}$ to total $\mathrm{Ca}^{2+}$ and $\mathrm{Mg}^{2+}$ efflux, calculated as described in the text. Each point represents the mean \pm SEM of five to ten determinations. $\mathrm{O}-\mathrm{O}=$ net $\mathrm{Ca}^{2+}$ efflux; - net $\mathrm{Mg}^{2+}$ efflux

and then rewarmed. In view of this difficulty, a new strategy was employed. If the effect of cooling and its reversal on rewarming were due to changes in the flux of divalent cations across the sarcolemma, then, irrespective of the direction of these changes, one of these effects should be eliminated in a medium where unidirectional flux was induced by the omission of $\mathrm{Ca}^{2+}$ and $\mathrm{Mg}^{2+}$ and the presence of the chelator, EDTA.

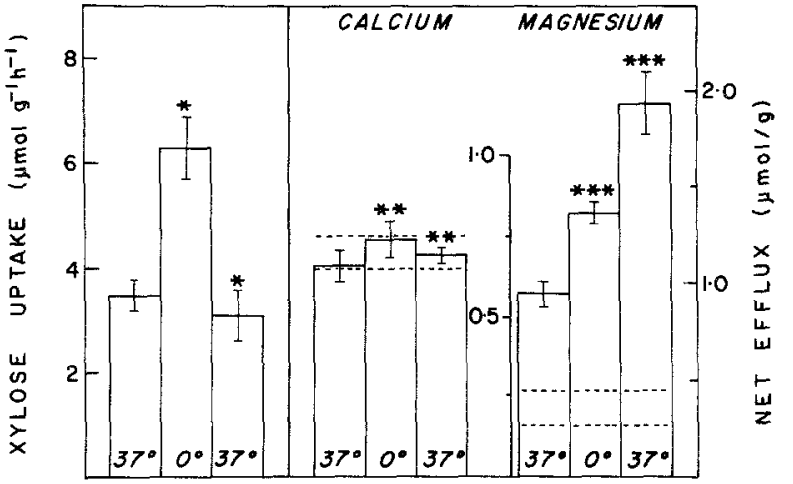

Fig. 6. Effect of cooling and rewarming on xylose uptake and net efflux of $\mathrm{Ca}^{2+}$ and $\mathrm{Mg}^{2+}$ in the presence of EDTA. Soleus muscles were incubated in $\mathrm{Ca}^{2+} / \mathrm{Mg}^{2+}$-free medium containing EDTA $(5 \mathrm{mmol} / \mathrm{l})$ using a three-stage procedure: first for $30 \mathrm{~min}$ at $37^{\circ} \mathrm{C}$ (preincubation), then for $3 \mathrm{~h}$ at $0^{\circ} \mathrm{C}$ (cool) and finally for $30 \mathrm{~min}$ at $37^{\circ} \mathrm{C}$ (rewarmed). Muscles were incubated in the same vessels throughout the experiment, hence the efflux of $\mathrm{Ca}^{2+}$ and $\mathrm{Mg}^{2+}$ shown is the cumulative efflux at each stage. . - - indicate the calculated values for extracellular $\mathrm{Ca}^{2+}$ and $\mathrm{Mg}^{2+}$ (from Fig. 5). Results shown are the mean \pm SEM of six determinations. Cool versus preincubation. * $p<0.02, * * p<0.05, * * * p<0.005$ Rewarmed versus cool $* p<0.005, * * \mathrm{NS}, * * * p<0.05$

Part of the $\mathrm{Ca}^{2+}$ and $\mathrm{Mg}^{2+}$ which will leak from the muscle into the incubation medium will be that which was present in the extracellular fluids on removal from the animal. From measurements of the $\mathrm{Ca}^{2+}$ and $\mathrm{Mg}^{2+}$ content of rat blood and blood plas$\mathrm{ma}$, the contribution of extracellular $\mathrm{Ca}^{2+}$ to overall net $\mathrm{Ca}^{2+}$-efflux has been calculated to be $0.65-0.73 \mu \mathrm{mol} / \mathrm{g}$ muscle and extracellular $\mathrm{Mg}^{2+}$ $0.25-0.45 \mu \mathrm{mol} / \mathrm{g}$ [13]. (These values, which define the upper and lower limits of the contribution of extracellular $\mathrm{Ca}^{2+}$ and $\mathrm{Mg}^{2+}$ to $\mathrm{Ca}^{2+}$ and $\mathrm{Mg}^{2+}$-efflux, are indicated in Figures 5 and 6 by the horizontal broken lines.) In the presence of $5 \mathrm{mmol}$ EDTA $/ 1$ net efflux of $\mathrm{Ca}^{2+}$ over a $3 \mathrm{~h}$ cooling period at $0{ }^{\circ} \mathrm{C}$ and subsequently for $1 \mathrm{~h}$ at $37^{\circ} \mathrm{C}$ did not exceed the calculated value for extracellular $\mathrm{Ca}^{2+}$ (Fig. 5). Conversely, net efflux of $\mathrm{Mg}^{2+}$ appeared to involve the release of intracellular $\mathrm{Mg}^{2+}$ during the period of cooling, and even more so during the subsequent rewarming period.

The effect of cooling on xylose uptake in the presence of EDTA was complicated by the fact that the chelator itself stimulates xylose uptake [13]. The stimulatory effect of EDTA was both rapid in onset and transient, and was no longer evident after $30 \mathrm{~min}$ exposure to the chelator [13]. To avoid this complication, muscles were preincubated for $30 \mathrm{~min}$ at $37^{\circ} \mathrm{C}$ in $\mathrm{Ca}^{2+} / \mathrm{Mg}^{2+}$-free medium containing EDTA before cooling. The stimulatory effect of cooling on xylose uptake and its reversal on rewarming were 
Table 1. Effect of A23187 on xylose uptake by cooled muscle in the presence of EDTA and EGTA

\begin{tabular}{llll}
\hline $\begin{array}{l}\text { Preincubation } \\
\text { details }\end{array}$ & Additions & \multicolumn{2}{l}{ Xylose uptake $\left(\mu \mathrm{mol} \mathrm{g} \mathrm{g}^{-1} \mathrm{~h}^{-1}\right)$} \\
\cline { 3 - 4 } & & Control & A23187 \\
\hline- & - & $3.1 \pm 0.5(5)$ & $2.9 \pm 0.3(5)$ \\
Cooled & - & $6.6 \pm 0.3(7)$ & $7.0 \pm 0.4(7)$ \\
- & EDTA & $3.9 \pm 0.4(7)$ & $4.2 \pm 0.3(7)$ \\
Cooled & EDTA & $6.4 \pm 0.4(7)$ & $4.9 \pm 0.2(7)^{\mathrm{a}}$ \\
- & EGTA & $3.3 \pm 0.2(5)$ & $2.8 \pm 0.3(5)$ \\
Cooled & EGTA & $7.8 \pm 0.2(8)$ & $7.9 \pm 0.3(8)$ \\
\hline
\end{tabular}

All the muscles were preincubated for $30 \mathrm{~min}$ at $37^{\circ} \mathrm{C}$ in $\mathrm{Ca}^{2+}$ / $\mathrm{Mg}^{2+}$-free medium $\pm \mathrm{A} 23187(2.5 \mathrm{mg} / 1)$. Some were then incubated a further $3 \mathrm{~h}$ at $0{ }^{\circ} \mathrm{C}$ in the same medium. Where indicated, the incubation medium also contained EDTA $(5 \mathrm{mmol} / \mathrm{l})$ or EGTA $(5 \mathrm{mmol} / \mathrm{l})$. Values are expressed as mean $\pm \mathrm{SEM}$; (number of observations in parentheses)

a $\mathrm{A} 23187$ versus control, $p<0.005$

Table 2. Effect of A23187 on net efflux of calcium and magnesium from soleus muscle

\begin{tabular}{llllll}
\hline $\begin{array}{l}\text { Pre- } \\
\text { incubation } \\
\text { details }\end{array}$ & \multicolumn{2}{c}{$\begin{array}{l}\text { Net calcium efflux } \\
(\mu \mathrm{mol} / \mathrm{g})\end{array}$} & & \multicolumn{2}{c}{$\begin{array}{c}\text { Net magnesium efflux } \\
(\mu \mathrm{mol} / \mathrm{g})\end{array}$} \\
\cline { 2 - 3 } \cline { 5 - 6 } & Control & $\mathrm{A} 23187$ & & Control & $\mathrm{A} 23187$ \\
\hline $\begin{array}{l}37^{\circ} \mathrm{C}, \\
30 \mathrm{~min}\end{array}$ & $0.58 \pm 0.04$ & $0.60 \pm 0.03$ & & $0.71 \pm 0.05$ & $1.33 \pm 0.05^{\mathrm{a}}$ \\
$0^{\circ} \mathrm{C}, 3 \mathrm{~h}$ & $0.09 \pm 0.03$ & $0.08 \pm 0.03$ & & $0.75 \pm 0.06$ & $0.76 \pm 0.04$ \\
\hline
\end{tabular}

Soleus muscles were incubated for $30 \mathrm{~min}$ at $37^{\circ} \mathrm{C}$ in $0.5 \mathrm{ml}$ of $\mathrm{Ca}^{2+} / \mathrm{Mg}^{2+}$-free medium containing EDTA $(5 \mathrm{mmol} / \mathrm{l})$ \pm A23187 (2.5 mg/l). At this point the muscles were removed, rinsed in $\mathrm{Ca}^{2+} / \mathrm{Mg}^{2+}$-free medium containing EDTA (but not A23187), blotted on damp filter paper and incubated for a further $3 \mathrm{~h}$ at $0{ }^{\circ} \mathrm{C}$ in fresh medium containing EDTA $\pm \mathrm{A} 23187$. The release of $\mathrm{Ca}^{2+}$ and $\mathrm{Mg}^{2+}$ into the medium during these two incubation periods is shown separately (c. f. Fig. 6). Values are expressed as mean \pm SEM of seven determinations.

a A23187 versus control, $p<0.001$

readily demonstrable in the presence of EDTA (Fig. 6). The corresponding efflux of $\mathrm{Ca}^{2+}$ and $\mathrm{Mg}^{2+}$ under these conditions is also shown in Figure 6. The release of $\mathrm{Ca}^{2+}$ occurred principally during the initial $30 \mathrm{~min}$ preincubation period at $37^{\circ} \mathrm{C}$. There was a further small release of $\mathrm{Ca}^{2+}$ during the cooling period, but no change occurred during the final rewarming period. The amount of $\mathrm{Ca}^{2+}$ which appeared in the incubation medium did not exceed the calculated value for extracellular $\mathrm{Ca}^{2+}$. Conversely, intracellular $\mathrm{Mg}^{2+}$ was released during all stages of the experiment.

The final experiments in this series examined the influence of the ionophore (A23187) on the stimulatory effect of cooling in $\mathrm{Ca}^{2+} / \mathrm{Mg}^{2+}$-free medium in the presence of EDTA. There was no effect of A23187 $(2.5 \mathrm{mg} / 1)$ alone on either the rate of xylose uptake measured after an initial $30 \mathrm{~min}$ period at $37^{\circ} \mathrm{C}$ in
$\mathrm{Ca}^{2+} / \mathrm{Mg}^{2+}$-free medium, or on the subsequent effect of cooling (Table 1). In the presence of EDTA, A23187 did not alter xylose uptake measured after the initial $30 \mathrm{~min}$ period at $37^{\circ} \mathrm{C}$; however, under these conditions the ionophore depressed the stimulatory effect of cooling. This effect of A23187 was not observed when EDTA was replaced by an alternative chelator, EGTA. In the presence of EDTA there was no effect of A23187 on net efflux of $\mathrm{Ca}^{2+}$ (Table 2); however, the ionophore did stimulate the release of $\mathrm{Mg}^{2+}$. This effect was seen during the period of preincubation at $37^{\circ} \mathrm{C}$ but not during the cooling period.

Because the action of A23187 may lead to the uncoupling of mitochondrial oxidative-phosphorylation, we asked whether the inhibitory effect of A23187 shown in Table 1 might be due to the lowering of muscle ATP. ATP was lowered when muscles were exposed to A23187 for $30 \mathrm{~min}$ in the presence of EDTA (control, $3.3 \pm 0.1$ versus A23187, $2.8 \pm 0.1 \mu \mathrm{mol} / \mathrm{g}$, $p<0.005, n=5$ ). However, A23187 also produced a similar change in ATP when musles were incubated in the absence of the chelator. As A23187 did not block the effect of cooling unless EDTA was also present, it is unlikely that this action of the ionophore is due to its rather limited effect on ATP.

\section{Discussion}

As indicated in the introduction to this paper, the stimulatory effect of cooling provides yet another probe to examine the sugar transport system in muscle, and in particular its regulation by intracellular metabolism. In common with many other "insulinlike" agents $[6,10,13]$, cooling did not stimulate xylose uptake to the same extent as insulin, and did not have any further effect when sugar transport was stimulated maximally by insulin. Conversely, even sub-maximal concentrations of insulin stimulated xylose uptake in cooled muscles. According to Kono et al. [18], cooling abolishes the stimulatory action of insulin on sugar transport in the adipocyte. Clearly, this is one aspect where the process of sugar transport in muscle differs from that in the adipocyte.

Cooling and anoxia each stimulated xylose uptake to the same extent. Cooling did not further stimulate sugar transport in anaerobic muscle and anoxia did not stimulate xylose uptake above the rate achieved in cooled muscle. This suggests that the effects of cooling and anoxia could share a common mechanism. It has been proposed that the stimulatory effect of anoxia is a consequence of the lowering of oxidative ATP $[5,6]$. The stimulatory effect of cooling cannot be due to the depletion of muscle ATP, but 
rather to its inability to function at $0{ }^{\circ} \mathrm{C}$. Thus the stimulatory effects of anoxia, uncouplers and cooling all appear to involve the disruption of some ATP-dependent process whose action serves to limit sugar transport.

The most likely explanation for an ATP-linked effect of cooling is that ATP provides energy for the maintenance of some ionic gradient. Cooling, by depressing the activity of the ion pump, would lead to the disruption of the gradient through diffusion and hence the activation of sugar transport. This would be reversed on rewarming by the re-establishment of the gradient, the reversal being temperature-dependent.

The experiments presented in the latter half of this paper sought to identify the system concerned. Bihler [19] has suggested that the stimulatory effect of anoxia may be due to the lack of oxidative ATP for the sarcolemmal sodium-potassium-ATPase. The release of potassium from the muscle on cooling and its subsequent uptake on rewarming are consistent with a mechanism for the cooling effect involving the sodium-pump. However, as the effect of cooling on sugar transport was still reversed when the re-entry of potassium was inhibited with ouabain, this would seem to exclude this possibility. Similarly, the effect of cooling does not appear to involve the movement of the divalent cations, calcium and magnesium, across the sarcolemma. Thus, when muscles were incubated in calcium/magnesium-free medium containing EDTA to induce the unidirectional efflux of calcium and magnesium from the muscle, cooling still stimulated xylose uptake and this effect was reversed on rewarming. This leaves us with the conclusion that the effect of cooling cannot be due to changes taking place across the sarcolemma, but rather to changes occurring within the muscle fibre itself.

As the ionophore (A23187) will increase the permeability of the cell membrane to divalent cations [20], it could be expected that the combined actions of A23187 and EDTA might have a greater influence on intracellular cations than EDTA alone. By promoting the efflux of divalent cations, this would tend both to lower and to counteract any increase in the cytoplasmic cation concentration. The combination of A23187 and EDTA depressed the stimulatory effect of cooling (Table 1). (Because this combination did not stimulate basal sugar transport, it follows that stimulation is not achieved by lowering the cation concentration; that is, the cation itself is not an inhibitor of sugar transport.) These results suggest that cooling activates sugar transport by increasing the cytoplasmic concentration of some divalent cation and that A23187 and EDTA antagonize this effect by promoting the efflux of this cation.

Thus far, we have not attempted to specify which divalent cation is involved. Clausen et al. [10] proposed that the effect of cooling on muscle sugar transport is due to increased cytoplasmic calcium levels. The action of A23187 to depress the effect of cooling on sugar transport in the presence of EDTA could have been due to an increase in the efflux of calcium, thus preventing any intracellular accumulation. However, the effect of A23187 on sugar transport in cooled muscles was no longer evident when EDTA was replaced by EGTA. As both chelators have the same affinity for calcium [13], the requirement for EDTA, but not EGTA, suggests that the effect of A23187 was not concerned with intracellular calcium, but with some other cation. There is a strong possibility that magnesium could be the cation involved. The inability of EGTA to substitute for EDTA could be related to the fact that the affinity of EGTA for magnesium at $\mathrm{pH}$ 7.4 is $2 \times 10^{4}$ times lower than that of EDTA [13]. This would be consistent with the observation that A23187 promoted net efflux of magnesium but not calcium. The possibility that magnesium may play an important role in the regulation of muscle sugar transport is perhaps the most important finding to emerge from these studies.

Rubin has proposed that a number of coordinated metabolic processes in chick embryo fibroblasts, including glucose transport, are regulated by the availability of magnesium for transphosphorylation reactions $[21,22]$. This effect relates to glucose transport itself, not the subsequent phosphorylation step [22]. As presently formulated, there is no phosphorylation reaction directly involved in the process of sugar transport in either muscle or fibroblast. In cultured chick fibroblasts, the effect of magnesium on glucose transport appeared to involve protein synthesis [22]; hence it is not immediately apparent how the model proposed by Rubin may relate to the regulation of sugar transport in muscle.

Randle and Smith [5] originally suggested that ATP could serve as a feedback inhibitor to regulate the sugar transport system in muscle. Recent studies in this laboratory lend support to this theory [6]. On the basis of the arguments presented above, we would propose that the role of ATP in this system is to provide energy for an intracellular magnesium pump, which operates to inhibit sugar transport by lowering the cytoplasmic magnesium concentration. The disruption of this pump either by cooling, or in anaerobic muscle by a lack of oxidative ATP [6], leads to a magnesium-dependent activation of sugar transport. The nature of this pump and the manner in which magnesium exerts its influence on sugar transport remain to be determined.

Acknowledgement. This work was supported by a grant from the Australian National Health and Medical Research Council. 


\section{References}

1. Czech MP (1980) Insulin action and the regulation of hexose transport. Diabetes 29:399-409

2. Elbrink J, Bihler I (1975) Membrane transport: its relation to cellular metabolic rates. Science 188: 1177-1184

3. Clausen T (1975) The effect of insulin on glucose transport in muscle cells. Curr Top Membr Transp 5: 169-226

4. Czech MP (1977) Molecular basis of insulin action. Annu Rev Biochem 46: 359-384

5. Randle PJ, Smith GH (1958) Regulation of glucose uptake by muscle. II. The effects of insulin, anaerobiosis and cell poisons on the penetration of isolated rat diaphragm by sugars. Biochem J 70:501-508

6. Korbl GP, Sloan IG, Gould MK (1977) Effect of anoxia, 2,4dinitrophenol and salicylate on xylose transport by isolated rat soleus muscle. Biochim Biophys Acta 465:93-109

7. Czech MP(1976) Current status of the thiol redox model for the regulation of hexose transport by insulin. J Cell Physiol 89: 661-668

8. Livingston JN, Gurny PA, Lockwood DH (1977) Insulin-like effects of polyamines in fat cells. Mediation by $\mathrm{H}_{2} \mathrm{O}_{2}$ formation. J Biol Chem 252: 560-562

9. May JM, De Haen C (1979) Insulin-stimulated intracellular hydrogen peroxide production in rat epididymal fat cells. J Biol Chem 254: 2214-2220

10. Clausen T, Elbrink J, Dahl-Hansen AB (1975) The relationship between the transport of glucose and cations across cell membranes in isolated tissues. IX. The role of cellular calcium in the activation of the glucose transport system in rat soleus muscle. Biochim Biophys Acta 375:292-308

11. Yu KT, Gould MK (1978) Permissive effect of ATP on insulinstimulated sugar transport by rat soleus muscle. Am J Physiol 234: E407-E416

12. Yu KT, Gould MK (1978) Effect of prolonged anaerobiosis on ${ }^{125} \mathrm{I}$-insulin binding to rat soleus muscle: permissive effect of ATP. Am J Physiol 235: E606-E613

13. Yu KT, Keo L, Gould MK (1980) Stimulatory and inhibitory effects of EDTA on sugar transport by rat soleus muscle. Cell Calcium 1:337-347

14. Sloan IG, Korbl GP, Gould MK (1976) Short-term measurement of D-xylose uptake by isolated rat soleus muscle. Mol Cell Endocrinol 4:223-237
15. Bihler I (1968) The action of cardiotonic steroids on sugar transport in muscle in vitro. Biochim Biophys Acta 163:401-410

16. Bihler I, Sawh PC, Elbrink J (1976) A specific sugar transport mechanism in smooth muscle and its regulation. Can $\mathbf{J}$ Physiol Pharmacol 54:254-261

17. Kohn PG, Clausen T (1971) The relationship between the transport of glucose and cations across cell membranes in isolated tissues. VI. The effect of insulin, ouabain and metabolic inhibitors on the transport of 3-0-methylglucose and glucose in rat soleus muscles. Biochim Biophys Acta 225:277-290

18. Kono T, Robinson FW, Sarver JA, Vega FV, Pointer RH (1977) Actions of insulin in fat cells. Effects of low temperature, uncouplers of oxidative phosphorylation and respiratory inhibitors. J Biol Chem 252: 2226-2233

19. Bihler I (1972) Ionic effects in the regulation of sugar transport in muscle. In: Mehlman MA, Hansen RW (eds) The role of membranes in metabolic regulation. Academic Press, New York, pp 411-422

20. Reed PW, Lardy HA (1972) Antibiotic A23187 as a probe for the study of calcium and magnesium function in biological systems. In: Mehlman MA, Hansen RW (eds) The role of membranes in metabolic regulation. Academic Press, New York, pp 111-131

21. Rubin H(1976) Magnesium deprivation reproduces the coordinate effects of serum removal or cortisol addition on transport and metabolism in chick embryo fibroblasts. J Cell Physiol 89: 613-626

22. Bowen-Pope DF, Rubin H (1977) Magnesium and calcium effects on uptake of hexoses and uridine by chick embryo fibroblasts. Proc Natl Acad Sci USA 74: 1585-1589

Received: 6 January 1981

and in revised form: 25 May 1981

Dr. M. K. Gould

Department of Biochemistry

Monash University

Clayton, Victoria

Australia, 3168 